\title{
The Girls are Better at Language Learning: A Comparative Approach
}

\section{Lokman Coskun}

\author{
Lecturer at Beder University, a PhD Candidate at European University of Tirana \\ email-1: Icoskun@beder.edu.al, email-2: lokmancoskun@hotmail.com
}

\section{Doi:10.5901/jesr.2014.v4n2p17}

\begin{abstract}
The sex plays a very important role in language learning when compared to opposite sex. Some factors such as; cognitive, social and educational are essential for better learning foreign language. Each factor functions differently in boys and girls. But the girls have the combination of all factors when compared to boys. This study investigates the motivational factors for English language learning of Albanian private school students (girls). The qualitative and quantitative methods were was employed together. A questionnaire was distributed among class 10 and 11 students to obtain data. The study was carried out in second semester of academic year in two separate schools requesting anonymity. The results reveal that private school students (girls) have more instrumental and intrinsic motivation for English language learning, by dint of its usefulness in career planning and also students' utilitarian approach for learning English language. The limitation is that less students participated in the questionnaire. If there were more than 300 participants, it would increase the reliability of the study. For further study, more participants should be considered. This research revealed that private school students'(girls) motivation towards English language learning is better than boys, because Girls have a combination of social, cognitive and educational factors that affect better foreign language learning.
\end{abstract}

Keywords: Language Learning, Motivation, Sex, Private School.

\section{Introduction}

The role of the sex seems very important in language learning in terms of motivation of the students. Not only motivation, achievement, and attitudes of the students, but also cognitive, social and educational factors are considered very essential in language learning. With the aid of those factors, the researcher wants to identify the role and effect of them for better command of the language learning through comparing both boys and girls.

The effect of each factor influences in various ways for boys and girls. Actually, girls take into account the whole factors, but boys consider some of the factors while learning language. Comparing boys and girls in language learning are important due to individual and gender differences and expectations from learning goals. We need to know between the relations of the above-mentioned-factors and gender differences for finding fruitful outcomes in terms of motivation of both students.

The present gathered data explains very meaningful results for the study such as; girls are successful and more motivated in language learning when compared to boys due to having a combination of social, educational, cognitive, motivation, achievement, and attitudes factors. And the girls give emphasis on the whole factors due to their inborn characteristics.

Individual skills make themselves felt in language learning. Especially, through four learning methods such as; reading, speaking, writing, and listening. The girls definitely demonstrate more achievements in those language learning methods because of their integrative attitudes towards a particular language learning. Whereas, the boys are likely to show instrumental reason due to their utilitarian attitudes towards the language.

On the other hand, the girls have natural feature for speaking more than boys. This characteristics might channelize girls to learn language better and more motivated to a target language than boys. This inherent feature gives more opportunities to girls and direct them to do their best, because intrinsic and extrinsic factors draw the attention of the students to satisfy and obtain their learning achievements with the help of motivation and cognitive approaches and also through the effects of social, educational influences.

Motivation affects performance in learning process. The study treats motivation of the students in terms of gender difference. Learning language becomes a must for the development of the countries.

Albania is aware of the importance of language learning and its benefits for the development of the country, and foreign languages mainly English appears very important for international relations, because with the help of a foreign 
language, the countries increase their relations with other countries. Therefore, many students wanted to learn languages, and it becomes a government policy. Moreover, motivation of the students play important role, due to necessity of learning language and also without motivation, language learning is considered very difficult.

Demand for language learning increased and private institutions appeared as requirement to meet the demand of language learning. Name of the private schools and their priorities as the medium of teaching increased the motivation of the students for language learning. Increasing the motivation of the learners is needed to make learning process easy. Otherwise, this learning process is likely to be challenging for teachers.

The present study utilized both quantitative and qualitative methods for collecting data. The methodology was questionnaire to compare single-sex schools for collecting data. The gender was considered an important factor for motivation in separate school environment.

Even though motivation is an abstract concept, but the 'motivation is an abstract, hypothetical concept that we use to explain why people think, behave as they do.' says Dörnyei, Z. (2001, p:1). Single sex schools provide successful outcomes in learning process in terms of motivation.

Single sex schools appear essential for long term academic achievements, and better motivation. Especially, the students are coming from rural areas become more successful in learning language.

\section{Literature Review}

"The most effective way to get insight into the learning process is to study the learners' attitude and motivation towards learning English language." Besides, "learning can only happen if certain affective conditions, such as positive attitudes, self-confidence, low anxiety, exist and that when these conditions are present input can pass through the affective filter and be used by the learner." says Gömleksiz, M. N. (2001).

According to Cavallo, Rozman, Blinkenstaff, \& Walker, (2003) "Achievement motivation is students' motivation toward performance goals (such as earning high grades, getting praise, or performing better than other students) or toward learning goals (such as learning something new, learning for the sake of learning, or improving oneself). Because, "Achieving motivation lets the learner a desire to learn a language." expresses Gömleksiz, M. N. (2001).

On the other hand, According to Glynn, S.M., et, al., (2007) the female students are "more likely to attend class on time, sit in the front of the class, take notes, study the textbook, and study in an organized way-all behaviors associated with a relatively high motivation to learn." Also, the "girls' tend to demonstrate significantly more positive attitudes than boys do, recognizing also that they are more successful in learning languages than boys." states Muhammad, A.. et. al., (2013). He adds that the "motivation to learn is "a student's tendency to find academic activities meaningful and worthwhile and to try to derive the intended academic benefits from them."

This present study deals with gender motivation and its main factors for motivating students better in learning process. Because, the "gender is supposed to have an important effect on attitude and motivation and learning process." expresses Muhammad, A,. et. al., (2013).

\section{Discussion}

Foreign language plays important role for communication and international relations everywhere in the world. To learn a foreign language requires more attention and motivation and the contribution of learning a foreign language to the development of the country is clear in this global world.

As side effect of the global world, Albania is also trying to improve its relations with many foreign countries and also organizing various international meetings and conferences. In this regard, foreign language is a must for it. So, many students are likely to learn it in a quick way due to the practical value of English language, Therefore, students' attention and motivation are necessary for better command of language learning process.

If the number of people who speak English is more, then it will improve international relation with different countries and contribute too much to the development of the country. That's why not only private schools but also single sex schools both for only boys and for only girls appears another good option to meet the demands of learning English language, especially it is good for the students who are coming from rural areas and middle class families.

Moreover, for academic purposes and job finding reasons, many students across Albania make plans to go abroad to reach their target learning and target money making due to practical value of English Language or other languages. Eventually, both girls and boys have practical reasons for learning a foreign language which provides them academic career, money, awards, and job. 


\section{Research Questions}

1. Single-sex schools motivate girls more than boys in terms of long-term academic achievements.

2. Girls are more motivated than boys towards learning English.

\section{Research Methodology}

A combination of both qualitative and quantitative methods were used to collect data. Two well-known Albanian private schools (single sex) which requested anonymity were selected to get productive outcomes. A 31-item survey questionnaire was used for the participants to assess the motivation of them towards learning English Language.

Both primary and secondary data were taken to figure out motivational factors to learn language in private school environment. The questionnaire methodology enriched this study to obtain due data. 235 non-English students including girls and boys participated in the survey to find out their appropriate option in the motivation. Gender was taken as demographic information. The survey questions were adapted from Glynn, S. M., \& Koballa, T., R., Jr. (2006) and earlier it was developed by them. SBSS statistics 21 version was utilized to get due data for the present study.

\section{Limitation of Study}

Two separate schools one for all all girls and one for all boys were taken for the questionnaire in order to find out motivation of the students towards language learning in order to better understand how and why the female students are more motivated to learn language when compared to male students in a private single sex school environment in Albania, but if more than two schools were considered then there will be more opportunities to compare male and female students to obtain more reliable data in the study. So, for next study regarding single sex school, the researchers need to treat more schools while applying a survey regarding motivation in language learning.

\section{Findings}

Motivation Scale (MS) was piloted with reasonable results. The present study aimed to examine the gender differences of the male and female students regarding their behaviors and motivation towards learning English Language, and SPSS (version 20) as used to collect data. Language learning is complex process and the students need motivation to overcome this process for better command of the target language. Especially, learning English language is a must in this global world.

Table1: Female Students

\begin{tabular}{|c|c|c|c|c|c|}
\hline & Frequency & Percent & Valid Percent & \multicolumn{3}{c|}{ Cumulative Percent } \\
\hline Valid & 2 & 1 & .8 & .8 & .8 \\
& 3 & 2 & 1.7 & 1.7 & 2.5 \\
& 4 & 17 & 14.2 & 14.2 & 16.7 \\
& 5 & 98 & 81.7 & 81.7 & 98.3 \\
& Earning a good English Language grade is important to me. & 1 & .8 & .8 & 99.2 \\
& $F$ & 1 & .8 & .8 & 100.0 \\
& Total & 118 & 100.0 & 100.0 & \\
\hline
\end{tabular}


Table2: Male students

\begin{tabular}{|c|c|c|c|c|c|}
\hline & Frequency & Percent & Valid Percent & \multicolumn{2}{|c|}{ Cumulative Percent } \\
\hline \multirow[t]{9}{*}{ Valid } & & & & & \\
\hline & 1 & 1 & .8 & .8 & 1.7 \\
\hline & 2 & 3 & 2.5 & 2.5 & 4.2 \\
\hline & 3 & 5 & 4.2 & 4.2 & 8.3 \\
\hline & 4 & 22 & 18.3 & 18.3 & 26.7 \\
\hline & 5 & 86 & 71.7 & 71.7 & 98.3 \\
\hline & Earning a good English Language grade is important to me. & 1 & .8 & .8 & 99.2 \\
\hline & M & 1 & .8 & .8 & 100.0 \\
\hline & Total & 117 & 100.0 & 100.0 & \\
\hline
\end{tabular}

According to frequency data, the result shows that female students are better at English language learning than male students when compared in terms of motivation of language learning. The frequency data are seen for female students as 98 percent, they strongly agree to get better grades when compared to male students and it is seen 86 percent as frequency data. Because, single-sex school environment is good at providing more positive outcomes for academic achievement, and also for long-term educational outcomes, more than that it is clear that those types of educational environments support future academic achievements that include career aspirations for girls, says Mael et. al., (2005).

Moreover, Mael et. al., (2005) states the importance of single-sex education for academic interest, for it provides socializing, and adds that this type of education gives emphasis on grades \& leadership, but less importance on money and attractiveness regarding relationships with both male students and female students.

\section{Conclusion}

The present study demonstrates that Albanian students learn English well, when they are motivated, and they are better motivated in single sex school environment. Motivation is essential for learning language. Because, "Studies on motivation show that motivated learners are more successful in second language acquisition." says Gömleksiz, M. N. (2001).

According to this study, the researcher says based on the present study; single sex school is a good option for motivation of the students, both in language learning and other academic achievement. In this environment, the female students are motivated than male students.

This study suggests that a single sex school learning environment makes the students more motivated when compared to co-education in terms of gender difference. Accordingly, motivational strategies will be different from coeducation. Actually, no researcher can say that there is a supernatural method in motivation, but suitable strategies in terms of motivation might be preferable to make the target students motivate and to create a positive learning environment with the help single-sex school based strategies.

The study offers that the curriculum designers in Albania should consider separate syllabus for females and males for better command of language learning process through putting into account the single sex school environment.

\section{References}

Cavallo, A.M.L., Rozman, M., Blinkenstaff, J., \& Walker, N. (2003). Students' learning approaches, reasoning abilities, motivational goals, and epistemological beliefs in differing college science courses. Journal of College Science Teaching, 33, 18-23.

Dörnyei, Z. (2001). Motivational strategies in the language classroom. Cambridge: Cambridge University Press. Retrieved on, 14/10/2013 http://lib.fr ee-col lege.org/view.php?id= 560972

Gömleksiz, M. N. (2001). The effects of age and motivation factors on second language acquisition. Firat University Journal of Social Science, 11(2), 217-224.

Glynn, S.M., Taasoobshirazi, G., \& Brickman, P. (2007). Nonscience majors learning science: A theoretical model of motivation. Journal of Research in Science Teaching, 44, 1088-1107.

Kim, S. (2011). Is Motivation Changeable? : Exploring the Possibility and Principle of Public Service Motivation Change. Korea University. Retrieved on, 14/10/2013 http://ajou.ac.kr/ seoyong/paper/ls\%20Motivation\%20Changeable-With\%20Cheouljoo\% 20Lee.pdf

Mael f., A. Alonso, D. Gibson, K. Rogers, and M. Smith. (2005). "Single-sex Versus Coeducational Schooling: A systematic review." 
Washington, DC: US Department of Education. Retrieved: 19/06/2013 Ng, K.T., Soon, S.T. \& Fong, S.F. (2010). Development of a Questionnaire to Evaluate Students' Perceived Motivation towards Science Learning Incorporating ICT Tool. Malaysian Journal of Educational Technology, 10(1), pp. 39-55.

Muhammad, A. and Mamuna G. (2013). Gender and Language Learning Motivation. Academic Research International, Vol. 4 No. 2 March 2013.

Zolt'n Dörnyei (1998). Motivation in second and foreign language learning. Language Teaching, 31, pp 117-135

Vaezi, Z., (2008). "Language Learning Motivation among Iranian Undergraduate Students." World Applied Sciences Journal, 5(1): 54-61 